\title{
THE COURTS AND ACCESS TO JUSTICE
}

\author{
Sir Ivor Richardson*
}

This article was presented as a lecture at the Australasian Law Teachers' Association Conference held at Victoria University of Wellington, 6 July 1999.

\section{INTRODUCTION}

Ensuring access to justice is one of the most basic functions of the State. Most of our legal rules are concerned with doing justice according to law to parties before the courts. But access to justice is concerned with how the State ensures that fair, efficient and expeditious dispute resolution can be achieved. It is access to justice that will be the broad theme of this paper.

As a preliminary comment, I suggest there are four relevant features of the justice system in a democracy. First, the orderly resolution of disputes is essential to the functioning of any democratic society. The law should be the means through which people can protect their rights and interests, and through which the community can be confident that disputes will be settled. The second feature of justice in a democracy is that the institutions of government are under the law. Parliament and the Executive are bound by the law just like every other person and body in New Zealand. The third feature is that the courts as the judicial branch of government have a particular role in the protection of human rights. And the fourth feature of justice in a democracy is that the equal protection of the law and the due process of the law underpin the resolution of disputes between citizen and citizen, and citizen and the State. That is fundamental to the functioning of democracy.

To a large extent any system of justice reflects the values of the particular society. Democracies such as ours place a high value on the equality and individuality of all its members. A balancing consideration to individual rights is the interests of the community. That weighing requires fine-tuning. The goal must be to provide a proper balance between the rights and obligations of individuals; balanced against the rights and

* President, New Zealand Court of Appeal. 
obligations of minority groups, including different generations, and particularly indigenous and ethnic minorities; and balanced against the rights and obligations of the community as a whole.

Within the broad theme of access to justice, and to focus on how rights must be balanced, I would like to address a number of topics. The title for this conference invites speakers to consider legal developments made over the course of the past one hundred years. I will not be quite so ambitious in my scope. In each area I will consider changes and advances that have been made in recent years and look ahead also to the future.

First, I propose to discuss the role and functioning of the Court of Appeal. One usually associates the term "access to justice" with the right to access trial courts, but the ability to access appellate courts may be equally important. And of course it is the area that I am best placed to comment on. I am concerned to examine how the Court of Appeal can balance its undoubted function as a developer of the law with its dispute resolution function; in other words, its function as a fair and efficient provider of justice to the parties appearing before it.

Second, I want to comment on the operation of the legal aid system in New Zealand. In its interim report on the Bill of Rights White Paper, the Justice and Law Reform Select Committee commented that unless the Bill of Rights provided some guarantees of assistance in gaining access to the courts, it would be "irrelevant to the mass of people within this society who do not enjoy the 'right of access to justice' at the present time". ${ }^{1}$ I will consider the current system as governed by the Legal Services Act 1991 and ask some questions about the level of assistance that must be provided "in the interests of justice".

Third, I will consider the extent to which the operations of the court system should be open to the public. The principle of open administration of justice is an important one and has been reaffirmed in countless decisions. But how far should that principle of openness extend in the television age? I will look at how that issue has been addressed in New Zealand.

\section{THE ROLE AND FUNCTIONING OF THE COURT OF APPEAL}

Turning first to the role of the Court of Appeal. An appellate court is said to have three functions. First, an appeal court is able to correct errors made in the lower courts. This function is directly concerned with doing justice to litigants as it ensures that the determination of their rights in the court below was made upon a correct understanding of

1 Justice and Law Reform Select Committee Interim Report of the Justice and Law Reform Select Committee: Inquiry into the White Paper, A Bill of Rights for New Zealand (Government Printer, Wellington, 1986). 
the law. Second, an appeal court supervises the functioning of trial courts. The availability of appeal to a single court ensures a consistency of approach towards the administration of justice throughout the country. Third, an appeal court enunciates and harmonises the law. There can be no doubt that it is a proper function of the courts to make law, whether it is through the interpretation of statutes or development of the common law. In fulfilling this role the court is less concerned with the parties before it, although they benefit from having the law correctly determined, than it is with the broader development of our law.

I venture to say that the competing demands of the dispute resolution function and the law-making one are more pressing on the New Zealand Court of Appeal than on similar courts in most other jurisdictions. Let me explain.

The first point is the sheer volume of cases dealt with by the Court of Appeal. We have very little ability to control the flow of cases reaching us because in the vast majority of cases appeals are as of right rather than by leave. This means that the number of cases we must hear is far greater than in final courts elsewhere. In 1997, the Court of Appeal determined 513 criminal appeals and 160 civil appeals. This number, which excludes a large number of miscellaneous motions, was slightly fewer than in 1996 and slightly more than in 1998. These figures represent a substantial increase from earlier times. Twentyfive years ago in 1983, the Court dealt with 263 criminal appeals and 109 civil appeals, and 25 years before that the totals were 51 and 35 respectively. In his report on appeals to the Privy Council, the Solicitor-General noted that in the period between 1987 and 1994 the Court's workload increased by 60 per cent. $^{2}$ The Court has responded to this increase, referred to in the United States as "the crisis of volume", with more active case management techniques, which I will discuss in a moment, and an increased use of divisional courts, particularly the criminal appeal division which now hears the majority of criminal appeals.

The number of cases reaching the Court of Appeal contrasts markedly with the figures in other countries. In 1997, the High Court of Australia (which has seven judges) gave 56 judgments, 49 being delivered by the full court and seven by single justices; the Supreme Court of Canada (with nine judges) delivered 107 judgments; the House of Lords (which has 12 full time Law Lords) gave 54; and the Supreme Court of the United States (with nine justices) delivered 90 judgments in its October 1996 to October 1997 term.

New Zealand judges also function with less in the way of assistance than their counterparts in other jurisdictions. We now, after considerable struggle, each have a judge's clerk to assist with research but this compares with two clerks per judge in the

2 Crown Law Office Report of the Solicitor-General to the Cabinet Strategy Committee on Issues of Termination and Court Structure (Crown Law Office, Wellington). 
High Court of Australia and the Supreme Court of Canada and three to four clerks per judge in United States Federal Courts of Appeal. In the United States Supreme Court each of the sitting Justices has four clerks except for Justice Stevens and Chief Justice Rehnquist who have three.

The second point is that the Court is carrying out two quite different functions. This is reflected in the allocation of cases to three and five judge courts. The great bulk of three judge cases are of immediate importance to the parties but they ordinarily have no wider impact on the continuing development of the law. In these cases the Court's primary function is to review the decision below and correct error. Where, however, a case raises issues of importance, including any legal, social and general economic considerations; or if there are conflicting decisions of lower courts; or if the Court is to be asked to depart from its own earlier decision, then it should be heard by a court comprising five or seven judges. Our Court of Appeal really functions both as a busy intermediate appellate court - with three judges assigned to hear cases - and also for practical purposes as a final tier of appeal - with five or seven judges sitting. We hear approximately 60 cases per year in the latter capacity, a number comparable with final courts in other jurisdictions.

The third point is that although the Court of Appeal is strictly speaking an intermediate court, as suggested a moment ago, it serves for most intents and purposes as a final appeal court. In 1997, the Privy Council determined 14 appeals from New Zealand. In 1996, it was only nine and last year it was just seven. In the past three years there have been only seven successful Privy Council appeals and during this period there have been just two successful appeals where the case was heard by a full court of five judges in New Zealand. In one of those cases the appeal was allowed on a ground not invoked as a basis for granting leave to appeal and in the other, a rare criminal appeal, the Privy Council held by three to two that it was not certain that the appellant would have been convicted in the absence of an irregularity at trial.

The low number of cases proceeding to London is not, I should point out, due to a restrictive approach towards the granting of leave. In 1997, only 13 leave applications were heard. Nor are Court of Appeal decisions frequently reviewed by way of leave applications to the Judicial Committee itself. This contrasts with the situation in, for example, the United States where, although very few appeals are heard in the Supreme Court from the decisions of state supreme courts and federal appeals courts, the Supreme Court does deal with a very large number of applications for leave, as I mentioned, as many as 7000 per year.

These figures demonstrate that the Court of Appeal serves a very real dispute resolution role for a large number of litigants. And yet the Court must also make final decisions on the development of the law in the vast majority of cases. Given that the parties before the Court are there to have their dispute resolved it is important that the 
Court deliver judgment expeditiously. An effective remedy is a timely one. A number of reports in recent years, including the Woolf report in $1996,{ }^{3}$ have stressed that efficiency and speed are important features of the right of access to justice.

This has been recognised in the Court of Appeal with the adoption of more active case management in recent years. Proactive caseflow management allows for the monitoring of appeals. For example, criminal appeals involving child complainants, pre-trial rulings, short sentences and bail matters are segregated out and given special priority. Active case management allows for the organising of uneven workflows and faster turn-around times avoid backlogs and facilitate timetabling. Most cases are disposed of within one month of the hearing and last year there were only a handful of judgments outstanding at the end of the year.

The system also remains sufficiently flexible to allow schedules to be altered to deal with urgent appeals. A striking example concerned the decision on behalf of Northland Health Limited not to provide or continue to provide dialysis for a sick patient. The High Court delivered its decision in Whangerei on the morning of 10 October 1997, the appeal papers were lodged early in the afternoon, we began hearing shortly after 5 o'clock, heard extensive submissions from counsel, and announced the decision dismissing the appeal shortly before midnight. Again, in 1999 we had to deal with two urgent last minute applications arising out of electricity reforms due to be finalised on 31 March and 1 April 1999. One we squeezed in on $30 \mathrm{March}$ and gave judgment the next day. In the second, the High Court injunction was granted on 31 March, counsel came to the Court of Appeal at 4 o'clock that day and met with the judges in chambers and a hearing was set down for 11 o'clock the next morning. Having read the papers late into the night before, when Colin Carruthers QC, who also appeared in the just mentioned Northland Health case, told us at 11 o'clock that agreement had been reached I half expected him to add "April Fool".

Case management requires an acknowledgement that no litigant should have an open ended right to be heard. In Ashmore $v$ Corporation of Lloyd's Lord Roskill commented that "[1]itigants are only entitled to so much of the trial judge's time as is necessary for the proper determination of the relevant issues". ${ }^{2}$ And in 1992 the present Chief Justice of Australia Sir Murray Gleeson said that "[m]ost judges nowadays accept a responsibility, not merely towards the particular litigants who are currently before them, but also to the others who are waiting in the queue". ${ }^{5}$

3 Rt Hon Lord Woolf Access to Justice: Final Report (Her Majesty's Stationery Office, London, 1996).

4 Ashmore v Corporation of Lloyd's [1992] 1 WLR 446, 448.

5 Sir Murray Gleeson "Access to Justice" (1992) 66 ALJ 270. 
The third consideration that I noted in my introduction is that the system of justice must serve both the legitimate interests of the parties and the wider public interest in the administration of justice. Litigation is not a private preserve of those immediately involved. The open, fair and effective functioning of the courts is fundamental to a democratic society. The performance of the judicial system influences economic decision making, social harmony, individual flourishing and community development. That crucial public interest in the justice system is a critical consideration in numerous justice questions.

None of this means that efficiency should be allowed to override quality and the need for careful deliberation. But case management is not focussed on reducing the amount of time judges spend actually writing and discussing any particular decision. Rather it is about ensuring that time is available to be spent on the case relatively promptly after it is heard. It is also important to ensure that the hearing time is well spent. When sitting on criminal cases we hear an average of two appeals per day. Civil cases take longer: the vast majority are heard in one day and a very few are heard over two or more days. In recent years the court has reduced the hearing times to this length through active case management. Hearing times are allocated in advance with input from counsel. Submissions, which follow a set format and are subject to a maximum length, are filed in advance and are read by the judges. By following these procedures we are able to move straight to the relevant issues on the day of the hearing.

Just as in the health system efficiency may be increased by reducing inpatient times, in the justice system the length of time people spend in that system is a factor in the efficient operation of the courts. Here I note that in recent years, according to one survey, the average length of a jury trial has increased by 40 per cent: a study of why this has occurred would be the first step in determining whether there is any scope for reduction.

Turning for a moment to cases dealing with the nature of disputes that may properly come before the courts, it should be pointed out that many issues in this area are far from settled. Two important cases in the Court of Appeal late last year concerned to some extent the right to access the courts. First, in Peters $v$ Davison, ${ }^{6}$ the Winebox case, Mr Peters argued successfully for the right to challenge certain findings of a commission of inquiry. Only such a court challenge, it was argued, could serve to remedy alleged slurs made on Mr Peters' reputation in alleged error of law. The judgments in Peters $v$ Davison stressed the principles that the courts have final responsibility for determining the law and that access to such determinations is not lightly to be denied. Second, in Choudry $v$ AttorneyGeneral, $^{7}$ the plaintiff argued for his right to access documents held by the New Zealand

6 Peters v Davison [1999] 2 NZLR 164 (CA).

7 Choudry v Attorney-General (1998) 16 CRNZ 278 (CA). 
Security Intelligence Service. Without these documents, it was said, the plaintiff could not pursue his civil claim against the service for what might be called "home invasion" and thereby obtain a meaningful remedy for an alleged violation of his rights. If all attempts to access relevant documents are unhesitatingly rebuffed by the claim of national security then there is no genuine possibility of access to justice. The judgment in that case emphasised that it is the final responsibility of the courts to balance fair trial rights against confidentiality concerns to determine where the interests of justice lie.

As well as access to the courts and expeditious hearings, it is also desirable that litigants and those coming after them have some certainty of result. A comparison between our Court of Appeal, the High Court of Australia and the Supreme Court of Canada reveals that currently our Court has far fewer dissents and significant differences of reasoning. There is of course a place for dissenting judgments, and a persuasive dissent today may well become the law some time in the future. But in general it is desirable to achieve certainty. Certainty is what the public expects from its judges.

It is interesting to contrast the reception of two very important recent cases. The first case I am thinking of is the House of Lords' judgment in Pinochet. ${ }^{8}$ Shortly after the ruling, The Economist commented that the "Law Lords have now written seven separate judgments, all of which disagree with the others on major points of law". ${ }^{9}$ The ruling, the newspaper said, is so "confusing that it is unlikely to be followed by courts anywhere but in Britain, and even British courts will have difficulty deciphering what it means." Although I do not endorse those comments I think that it shows that the public's expectation of clarity went unfulfilled. Contrast this with the Supreme Court of Canada's judgment in Reference Re Secession of Quebec. ${ }^{10}$ This judgment last year was billed as the most important ever decided by the Supreme Court. The Canadian Government, by way of Order in Council, asked the Court to consider whether or not the Province of Quebec has the right to secede unilaterally from the rest of Canada. Notwithstanding the diversity of the Supreme Court bench, a single judgment of the court, signed by all nine justices, was delivered. The balanced compromise presented by the Supreme Court was well received in both the English and French press.

\section{THE LEGAL AID SYSTEM}

The ability to access justice depends not only on the operation of the courts, but also on the ability to be represented before them. With that in mind I turn now to consider the

$8 \quad R v$ Bow Street Magistrate, ex parte Pinochet [1998] 3 WLR 1456; (No 3) [1999] 2 WLR 827.

9 The Economist, London, England, 27 March 1999.

10 Reference Re Secession of Quebec [1998] 2 SCR 217 (SCC). 
legal aid system. The right to appear before a court may be of little value in the absence of effective representation. It would be a poor reflection on the legal profession if it were ever to be suggested that a litigant in person is in as good a position to obtain justice as one represented by counsel. The right to be legally represented is of the most pressing importance to those facing criminal charges. This is recognised in section $24(\mathrm{f})$ of the New Zealand Bill of Rights Act 1990 which provides that persons charged: "Shall have the right to receive legal assistance without cost if the interests of justice so require and the person does not have sufficient means to provide for that assistance".

The section raises the question of what the interests of justice require. In particular, when do the interests of justice require an appeal and legal assistance to pursue that appeal? Can it be said that so long as there is a right of appeal to the Court of Appeal, and in most cases there is, then that right should be open to all? Should there be a right to receive state assistance to pursue an appeal, no matter how tenuous its legal basis? And if there is the right to receive assistance for one appeal, why not for a further appeal?

The inevitable link between socio-economic conditions and crime means that a great many persons coming before the courts on criminal charges do not have the means to pay for representation. In a survey of prison inmates and periodic detainees conducted in 1995, 100 per cent of respondents had at some time applied for and received criminal legal aid. ${ }^{11}$ When asked what they would do if refused legal aid for an appeal, 30 per cent responded that they would still try to get a lawyer, 25 per cent said that they would simply drop the appeal, with 39 per cent replying that they would handle it themselves.

Here I interpolate that refusing legal aid in circumstances where the appeal will proceed without it, is something of a false economy. Litigants in person consume an exaggerated amount of judicial time and resources.

As in the lower courts, criminal legal aid is available in the Court of Appeal if it is desirable in the interests of justice. The decision as to whether or not this is so is made by the Registrar in consultation with a Judge of the Court of Appeal. The system that the Court of Appeal has adopted to deal with legal aid applications was the subject of extensive analysis in Nicholls $v$ Registrar of the Court of Appeal, ${ }^{12}$ but suffice to say that applications are considered by three judges and their views are made known to the Registrar before the final decision is made. Where legal aid is refused the applicant may apply for a review and this is considered by a fourth judge. In deciding whether or not to recommend that the Registrar grant legal aid the principal consideration is whether there

11 Legal Servies Board In the Interests of Justice: An Evaluation of Criminal Legal Aid in New Zealand (Legal Services Board, Wellington, 1995).

12 Nicholls $v$ Registrar of the Court of Appeal [1998] 2 NZLR 385 (CA). 
is an arguable ground of appeal, that is that the appeal has an argument that could succeed. The gravity of the offence and all other surrounding circumstances are also taken into account.

The legal aid system in the Court of Appeal is thought by many to be highly unsatisfactory. In Nicholls $v$ Registrar of the Court of Appeal Tipping J commented: ${ }^{13}$

I respectfully question whether the Judges of what is effectively, for almost all cases, New

Zealand's final Court of Appeal, should be considering, for legal aid purposes, the viability of an argument, for example, that there is not enough evidence to support a conviction for

burglary, possession of cannabis for supply, or even a more serious crime. Even with the assistance (criticised though it was) of the clerks, the Judges (potentially four of them) each

have to consider the matter, often in some detail.

As for the Privy Council, although a right to appeal still exists in certain circumstances, legal aid is available in respect of those appeals only if the Minister of Justice or AttorneyGeneral agrees.

It is important that we think carefully as a society about the level of access to justice that people should be entitled to bearing in mind that resources are necessarily limited. Access to justice cannot require that the State ensures unlimited provision of legal services to everyone in every situation on a demand driven basis. That would unfairly divert resources away from other areas. As earlier noted, a consideration is that the administration of justice involves the use and so the allocation of necessarily limited resources. The criticism is often made that the courts provide a Rolls Royce system and that the only people who can indulge in litigation, apart from those who have to, are the rich and the legally aided. Justice may be priceless. But it is not costless. The acceptable resolution of disputes involves balancing human rights and other moral values, fairness considerations and resource constraints. My point is that proposals to limit legal aid cannot be dismissed out of hand as contrary to justice. Other public policy considerations involving competing claims on limited resources require a choice at the margin between expenditure on health, education, justice, social welfare, defence and so on. Just as in the decisions we make as individuals as to how we will spend our energies and our money, there are always policy trade-offs between efficiency, fairness and other individual and community values.

\section{MEDIA COVERAGE OF COURT PROCEEDINGS}

I turn now to discuss access to the courts by non-participants via the media. The televising of court proceedings has recently been the subject of a three-year pilot study in

13 Nicholls $v$ Registrar of the Court of Appeal above n 12, 443. 
New Zealand. The study was instituted to develop and test rules to govern television access and arose from a report of a working party of the Courts Consultative Committee.

In its report the working party considered arguments both for and against allowing courtroom proceedings to be televised. The strongest argument in favour is that through television, public access to the operation of the courts can be enhanced. Public perceptions of the integrity and performance of the justice system are crucial to maintaining respect for the rule of law and the role of the courts in a healthy democracy. Few members of the public have the time, resources or inclination to physically attend court sittings. The community that the courts exist to serve consists also of those who rely on media reporting for information on the justice system.

A second argument is that the televising of proceedings can help to ensure that the courts are operating fairly and efficiently. A bill introduced into the United States House of Representatives on the subject of televised court proceedings was actually called the "Sunshine in the Courtroom Act", an apparent reference to Louis Brandeis' remark that "sunshine is the best disinfectant" for ill-doings. The argument is similar to that made for the televising of Parliamentary and Select Committee proceedings: let the public see just what the actors in their system of government are up to.

Third, television can help educate the public about the court system. My impression is that the general public does not have a good understanding of how the New Zealand justice system operates. Indeed, the popularity of the new wave of courtroom dramas, such as "The Practice", probably means that New Zealanders have a greater familiarity with American courtroom procedure, to the extent that it is fairly represented in such programmes, than they do their own.

There does appear to be a desire on the part of the public to know more about the courts. Between two surveys conducted in 1996 and 1997 the percentage of people opposed to broadcasts from within the courtroom fell from 58 per cent to 35 per cent. And positive support for such broadcasting rose from 25 per cent to 39 per cent. Whilst cameras will probably never enter our courtrooms to the extent that they have in the United States, which has an entire commercial channel called Court TV, there is the potential for more.

There are, however, a number of well-founded fears about what greater televising might do. First is the effect that it may have on trial participants. Judges may be distracted, lawyers may grandstand, and witnesses and jurors may fear the loss of privacy. The pilot study has allayed many fears that cameras would be disruptive, but the privacy argument is an important one. As always the rights to free expression and freedom of the media must be balanced against privacy values. 
Second, there is the risk that important matters will be trivialised and that through editing, serious proceedings will be reduced to resemble "You Be The Judge", the tabloidstyle disputes programme. The reality of courtroom proceedings is that they are slow and deliberative. Given that television is principally an entertainment medium rather than an educational one, editors will have every incentive to show only the most sensational moments. This will give the public an unrealistic view of how the courts operate.

Third, there is a risk of unfair prejudice to accused persons, particularly if they are later acquitted. Although such prejudice may occur simply as a result of the trial itself, television extends its reach.

A set of rules on television coverage of court proceedings, derived from recommendations of the Courts Consultative Committee and designed to address the concerns mentioned above whilst expanding media coverage of the courts, has recently been agreed upon by High Court and District Court judges.

The former Chief Justice said that in formulating the rules "the judiciary has balanced the principles of open justice with the accused's right to a fair trial. The purpose of a set of rules and code of conduct is to ensure that, where expanded coverage is permitted, those principles are upheld." The rules begin with a presumption in favour of access but provide safeguards. For example one rule requires accurate, impartial and balanced coverage of proceedings and parties involved in unedited broadcasts of at least two minutes duration. Family Court and mental health hearings are excluded from the expanded coverage and any witness or party in civil proceedings who objects to being identified shall have the matter determined by a judge. A more detailed code of conduct relating to the coverage of courtroom proceedings will be developed in consultation with the media. With the co-operation of the media and within the framework of rules agreed upon by the judges it is expected that the public will be afforded greater opportunities to witness the workings of its justice system, without undue prejudice to the participants.

\section{CONCLUSION}

At the beginning of this address I suggested that the justice system should reflect the values of our society. The goal must be to provide a proper balance between individual rights and the rights of various groups and more broadly the rights, interests and obligations of the community as a whole. The purpose of this paper has been to illustrate how this balance is currently struck in three areas: the functioning of the Court of Appeal, the operation of the legal aid system, and the televising of courtroom proceedings. What is thought desirable in all three of these areas will undoubtedly change over time and there will always be the need for fine-tuning. Forums such as this provide a valuable opportunity for debate and reflection on how the justice system can best meet the expectations of the community. 
